\title{
İstatistiksel okuryazarlık modelleri ve bileşenlerinin incelenmesi
}

\author{
Timur Koparan
}

Bülent Ecevit Üniversitesi, Ereğli Eğitim Fakültesi, Zonguldak, Türkiye,timurkoparan@gmail.com

ÖZ Bu çalışmada gün geçtikçe önem kazanan istatistiksel okuryazarlık, istatistiksel okuryazarlık modelleri ve bileşenleri incelenmiştir. Bu modellerin ortak amacı öğrencilerin problemleri nasıl çözdüğünü anlamaktır. İstatistiksel okuryazarlık, istatistik eğitimi araştırmalarında yeni bir konudur. Bu yüzden bu konuda öğrenme, değerlendirme ve öğretimi geliştirmek için yapılan girişimlerin ortaya konulmasına ihtiyaç vardır. Son yıllarda istatistik konularının matematik öğretim programımızda daha çok yer almaktadır. Bu nedenle istatistik öğretiminde öne çıkan model ve bileşenleri daha önemli hale getirmiştir. Çalışmada istatistiksel okuryazarlığı geliştirmek için kullanılan iki model incelenmiş, bu modellerin bileşenleri, benzer ve farklı yönleri ortaya konulmaya çalışılmıştır. Araştırmanın, istatistiksel okuryazarlık modelleri ve bileşenleri hakkında farkındalık oluşturacağı istatistik öğretiminde zorlukların aşılmasında hem araştırmacı hem de öğretmenlere 1şık tutacağı düşünülmektedir.

\section{An examination of statistical literacy models and their components}

ABSTRACT In this study, statistical literacy which is gaining importance day by day, statistical literacy models and components are examined. The common goal of these models is to understand how students solved statistical problems. Statistical literacy a new contruct within statistics education and therefore to learn about it, in order to improve assessment and training required special attention to the interference. In recent years, statistical issues in mathematics education programs are given a lot of space than its predecessors. That's why statistical models and components have become important. In this study, two models are used to develop statistical literacy examined the models components, similar and different aspects were investigated. This study will create an awareness statistical literacy models and components. At the same time it will be useful for both researchers and teachers for overcoming the difficulties encountered in the teaching of statistics.

Keywords Statistical Literacy, Statistical Literacy Models, Statistics Education. 


\section{EXTENDED SUMMARY}

In recent years, the community of statistics educators seems to have agreed upon some major learning goals for students of statistics. One of them is statistical literacy. Statistical literacy has long been a subject of maths and statistical education, and many researchers have tried to define the nature of statistical literacy Statistical literacy necessitates knowing the meanings of statistical terms, understanding of the use of statistical symbols, identifying and interpreting the data representations. It can, in short, be defined as understanding and using basic statistical language and tools. Statistical literacy is not only used in maths but also it is employed as an efficient way of communication in presenting the developments and changes in any field studied. In addition to preparing the individuals for academic and business life, statistics plays a significant role in preparing them for life. In today's information-rich society, being statistically literate will give you an edge. It will make you more attractive to future employers and put you ahead of your competitors in the workplace. Broadening your statistical knowledge will enable you to engage in discussions and decision-making processes with authority, accuracy and integrity. People make use of their statistical skills, either aware or unaware, to understand, analyse, and interpret the statistical information and situations. When statistical news and data are presented in different forms to the students, they will need statistical knowledge in evaluation and interpretation process. One of the purposes of mathematics education is to enable the student to gain necessary skills to cope with this kind of information. Students should be able to read, understand and make critical evaluations of the data.

Models for statistical modes of literacy and problem solving have been developed, and continue to be developed, by teachers and researchers. The purpose of these models range from helping to understand how individual students solve problems to developing instruments for educational research. These models have arisen with particularperspectives and primary uses in mind. The purpose of this study is to analyze components associated with statistical literacy, statistical literacy models in terms of different perspective and to examine both differences and similarities among statistical literacy models. These models are thought to be useful to researchers and teachers in planning of the learning goals, designing of the learning tasks, and predicting of the kind of statistical learning and thinking. In this study, two statistical literacy models are discussed and by considering different aspects of these models are compared. These statistical models are Gal (2002) and Watson and Callingham (2003). These models are used to define and characterize the level of statistical literacy or components. Gal (2002) model involves both knowledge elements and dispositional elements. Knowledge elements are literacy skills, statistical knowledge, mathematical knowledge, context/world knowledge, critical questions. Dispositional elements are attitudes, beliefs and critical stance. Watson and Callingham (2003) model based on a general developmental model (SOLO Taxonomy). Context, sampling, data representation, average, chance, variation, inference, mathematical and statistical skills are components of this statistical literacy. It has six levels. This levels are idiosyncratic, informal, inconsistent, consistent non-critical, critical and critical mathematical. This model are used to determine the level of students' statistical literacy. Their study used archived data collected from two large- scale research project. Watson and Callingham (2003) model exhibit beneficial a purpose compared to the other. Both models are historical. Gal (2002) model arising from the discipline of statistics while Watson and Callingham (2003) model originating from statistics education research. There is emphasis on both models to be critical. These two models is seen as a statistical literacy tools which are reflecting statistical literacy.

Consequently, statistical literacy is essentially the ability to find, access, utilise, understand and communicate the story contained within the data. Sound understanding, interpretation and critical evaluation of statistical information can then contribute to decision making. The importance of statistical literacy in our information-rich society means that it has now become a core competency like reading and writing. Statistics infiltrate and influence every aspect of our life, via the media and advertisements, persuading us to agree with a certain point of view or take some kind of action. Therefore every person interest to be statistically literate, to have a good understanding of statistics and the ability to use and interpret them effectively and appropriately. At this point models can be usefull for us. If these models are known by teachers and researchers, they can be benefit for overcoming the difficulties encountered in the teaching of statistics in planning of the learning goals, designing of the learning tasks, and predicting of the kind of statistical learning and thinking. 


\section{GİRIŞ}

İstatistiksel haberler gazete, dergi, televizyon ve internet yoluyla hızlı bir şekilde yayılmaktadır. Bireyler nüfus sayımından, enflasyon oranlarına, seçim sonuçlarından borsadaki dalgalanmaya her gün önemli bilgiler içeren gerçek hayat konularına dayalı istatistiksel haberler ve bilgilerle karşılaşmaktadır. Bu haberler ve bilgiler yazılı ya da görsel medyada farklı formlarda olabilmektedir. Bazen bir metin, bir tablo, bir grafik bazen de ortalama olarak yüz yüze gelinen bu nicel verileri kullanmadaki yetersizlikler bir çalışanın, öğrencinin, tüketicinin daha bilgili ve etkili bir birey olmasına engel olmaktadır. Bu yüzden bir bireyin istatistiksel sonuçları yorumlama yeteneği ve iddia edilenlerle ilgili bir sorgulama yapabilmesi ve sonuçlara varabilmesi son derece önemlidir. Çoğu günlük aktiviteler akıllı karar almak için istatistiksel bir anlayış gerektirmektedir. İstatistiğin öneminin giderek artması sonucu istatistik, birçok ülkede matematik öğretim programında yerini almıştır (Makar \&Rubin, 2009; Shaughnessy, 2007; Shaughnessy \&Pfannkuch, 2004). İş, sanayi, istihdam, spor, sağlık, hukuk ve kamuoyu yoklama ile ilgili kararlar istatistiksel bilgi ve teknikler kullanılarak yapılır (Gal, 2004; Rumsey, 2002; Wallman, 1993; Watson, 2006).

Hooke (1983) istatistik kullanımında yaygınlaşma olmasına rağmen, istatistiğin kötü amaçlı kullanımındaki artışın bu yaygınlaşmaya eşlik ettiğini belirtmiştir. Bireyler, kendi iddialarını desteklemek için istatistiksel argümanları kullananlara karşı kendini savunmak için hazırlıklı değildir. Toplumda istatistiklerin kötü amaçlı kullanımının giderek artması nedeniyle, tüketilen bilginin kalitesi konusunda kamu bilincinin artırılması önemli bir ihtiyaçtır (Rumsey, 2002). Eğitimle ilgili bazı topluluklar (National Council of Teachers of Mathematics [NCTM], 2000) ve matematik öğretim programları (Milli Eğitim Bakanlığı [MEB], 2009) istatistiğe karşı kesinlikle eleştirel bir bakış açısı geliştirilmesi gerekliliğine vurgu yapmaktadır.

Günlük yaşamda istatistiğin öneminin farkına varılması ve istatistiksel bilgilerin istatistiksel okuryazarlıkla ilişkisi, matematik ögretim programlarının ve program geliştirenlerin ilgi odağ haline gelmesine sebep olmuştur (Gal, 1995; Rumsey, 2002; Watson, 2006). İstatistik konularının okullarda öğretilmesinin üç önemli sebebi vardır. Bunlar; günlük yaşamda yararlı olması, diğer disiplinlerde de kullanılan bir araç olması, eleştirel düşünmeyi geliştirmede önemli olmasıdır. Bu sebeplerden dolayı bazı topluluklar matematik öğretim programlarında sık sık istatistiğin özel konumuna vurgu yapmakta ve istatistik eğitimi ile ilgili özel tavsiyelerde bulunmaktadır (American Statistical Association [ASA], 2005; NCTM, 2000).

Tüm ülkelerde olduğu gibi ülkemizde de matematik öğretim programları ihtiyaç duyulduğunda yeniden düzenlenmektedir. Son olarak 2005 ve 2013 yıllarında matematik öğretim programında değişiklikler yapılmıştır. Yenilenen öğretim programları incelendiğinde veri okuma, verileri temsil etme, merkezi eğilim ve yayılım ölçülerini kullanma, veriden tahmin ve çıkarımlar yapma ve olasılık hesapları yapma gibi istatistiksel becerilere farklı sınıf düzeylerinde eskisinden daha çok yer verildiği dikkat çekmektedir(MEB, 2009; MEB, 2013). Bu durum çağın ihtiyaçları doğrultusunda istatistikle ilgili kazanımlara daha çok önem verildiğini göstermektedir. İstatistikle ilgili kazanımların aşamalı olarak daha geniş bir zaman dilimine yayılması öğrencilerin istatistiksel okuryazarlıklarının da aşamalı olarak geliştiğinin bir göstergesi olarak görülebilir.

\section{İstatistiksel Okuryazarlık}

İstatistiksel okuryazarlık çok uzun zamandır matematik eğitiminin ilgi konusu olmuştur ve birçok araştırmacı istatistiksel okuryazarlığı, istatistiksel bilgi ve istatistiksel muhakeme gibi kavramlardan ayr1 olarak tanımlamıştır (Wallman, 1993; delmas, 2002; Rumsey, 2002; Gal, 2002; Lehohla, 2002; Watson, 1997; Watson \&Callingham, 2003; Gal, 2004; Callingham \& Watson, 2005; Garfield \&BenZvi, 2007). İstatistiksel okuryazarlığın tanımı birçok araştırmacı tarafından yapılmıştır. Wallman (1993), karar vermede istatistiğin yardımcı olarak nasıl kullanılabileceğinin değerlendirmesi ve çevremizde her yerde olan istatistiksel sonuçları hem anlayabilme hem de değerlendirebilme olarak, Snell (1999), istatistiksel kavramları anlama ve en temel seviyede akıl yürütme yeteneği olarak, Garfield (1999) istatistiksel dilin anlaşılması: kelimeler, semboller, terimler ve grafikleri ve tabloları yorumlayabilme yeteneği olarak, Lehohla (2002) indeksler ve göstergeler gibi bir takım niceliksel bilgileri okuyup anlama yetisi olarak, Rumsey (2002) içinde bulunduğumuz bilgi çağında toplumun eğitimli bir ferdi olarak fonksiyon gösterebilme yeteneği olarak tanımlamıştır. Gal (2002) ise istatistiksel okuryazarlığın insanların istatistiksel bilgi ve verilerle ilgili tartışma veya rastlantı 
olgusunu yorumlama eleştirel bir gözle değerlendirme ve bunlara ilişkin görüşleri dile getirme becerilerini kapsadığını ileri sürmüştür.

İstatistiksel okuryazarlığın yukarıdaki tanımlarına dikkat edilirse, araştırmacılar üç hususa vurgu yapmaktadır. Bunlar; istatistiksel terimlerin anlamının ne olduğunun bilinmesi, istatistiksel sembollerin kullanımının anlaşılması, son olarak veri gösterimlerinin tanınması ve yorumlanabilmesidir. $\mathrm{Bu}$ doğrultuda istatistiksel okuryazarlık, istatistiğin araçlarını ve temel dilini anlamayı ve kullanmayı içerir, şeklinde tanımlanabilir. İstatistiksel okuryazarlığı tanımlayan araştırmacılar, tanımlar üzerinde ortak bir mutabakata varmasa da, bilgi çağında bireyleri daha etkin yapan, istatistiksel okuryazarlığın vasıfları, tutumları ve bilgiyi kuşatır olduğu konusunda aynı fikirdedir. Medya uygun bazı mükemmel haberler vermesine rağmen, uygun olmayan ya da yanıltıcı birçok veri gösterimi de sunmaktadır. Bu nedenle sayısal delillerle akıl yürütmek oldukça zor görünmektedir.

Literatürde yer alan çeşitli istatistiksel düşünme, istatistiksel muhakeme ve istatistiksel okuryazarlık modelleri vardır. Bu çalışmada istatistiksel düşünme ve istatistiksel muhakemeden ayrı olarak istatistiksel okuryazarlık modellerine odaklanılarak (Gal, 2002; Watson \&Callingham 2003) bu modellerin bileşenleri, benzer ve farklı yönlerinin karşılaştırılması amaçlanmıştır. Literatürde yer alan bu iki istatistiksel okuryazarlık modelinden Gal (2002) modeli, istatistik alanında yapılan çalışmalar, Watson ve Callingham (2003) modeli ise istatistik eğitimi alanında yapılan çalışmalar sonucu oluşmuştur. İlki istatistiksel okuryazarlık içinde olması gereken bileşenleri tanımlarken, ikincisi öğrencilerin istatistiksel okuryazarlık seviyelerini her bir bileşen ve seviyede kategorilendirmiştir. Watson ve Callingham (2003) modelinde, Gal (2002) modelindeki bileșenler göz önünde bulundurulmuştur.

\section{İstatistiksel Okuryazarlık Modeli}

İstatistiksel düşünme, istatistikse muhakeme, istatistiksel okuryazarlık matematik öğretim programının bir parçası olmaya başlayınca öğrencilerin hem istatistiksel teknikleri kullanma becerileri hem de eleştirel değerlendirme becerilerinin gelişimini daha iyi görebilmek için araştırmacılar çeşitli modeller geliştirmişlerdir. Bunlardan en çok öne çıkanı Gal (2002) tarafından geliştirilen istatistiksel okuryazarlık modelidir. Literatürde birçok araştırmacı istatistiksel okuryazarlığı tanımlamada farklı kavramsal tanım ve bileşenler kullanmıştır. Gal (2002), istatistiksel okuryazarlığ 1 inceleyecek bir modelin bu çok yönlü kavramları oluşturan çok çeşitli bileşenleri içermesi gerektiğini düşünmüştür. Gal (2002) Modeli sadece istatistiksel okuryazarlık modeli değil aynı zamanda literatürde istatistiksel okuryazarlığı tanımlayan yedi kavramsal bileşenin tümünü içeren bir yapıdadır. Şekil 1'de Gal'ın istatistiksel okuryazarlık modeli görülmektedir. Burada her bir bileşen ayrıntılı olarak tartışılmıştır.

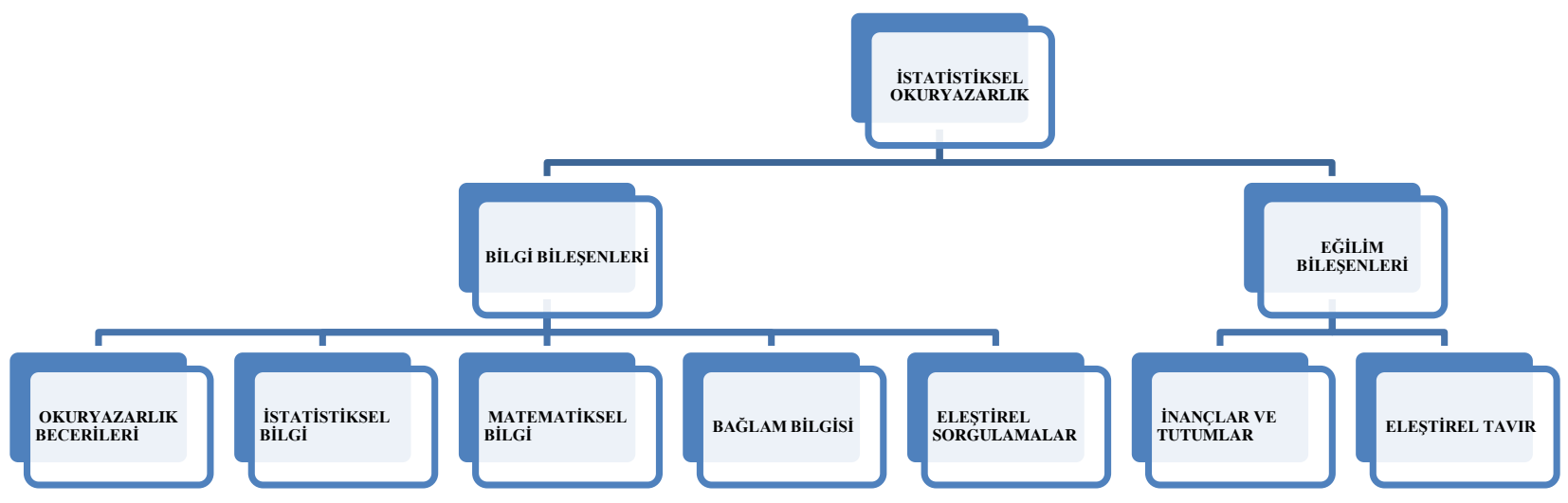

Şekil 1. İstatistiksel Okuryazarlık Modeli ve Bileşenleri

\section{Bilgi Bileşenleri}

Gal'ın (2002) modeli beş bilgi bileşeninden oluşmaktadır. Okuryazarlık becerileri, İstatistiksel bilgi, matematiksel bilgi, bağlam bilgisi, eleştirel sorgulama. Gal'a (2002) göre bu bileşenler, bireylerin 
günlük yaşamda farklı ortamlarda karşılaştığı veri ile ilgili düşünceleri ve istatistiksel bilgiyi eleştirel değerlendirme ve yorumlama işini nasıl yaptı̆̆ını inceler.

Okuryazarlık Becerileri: İlk bilgi bileşeni okuryazarlık becerileri, uzun ya da kısa olarak verilen bir metinde istatistiksel mesajın veya çok az kelime içeren bir grafiğin anlaşılmasını içerir. Okuyucular, istatistiksel mesajı oluşturanlar tarafından kullanılan rastgelelik, temsilci, yüzde, ortalama gibi istatistikle ilgili belirli terimlerin içeriğe göre ne anlama geldiğini anlamalıdır. Çoğu zaman terimlerin anlamı iletiyi oluşturanlar tarafından açıklanmaz. Örneğin istatistiksel çalışmalarda sonuçların tartışılmasında çoğunlukla hata payı, örnekleme hatası kullanılır. Bu yüzden istatistiksel okuryazar olmak için bir birey ilk olarak genel okuryazarlık becerilerine sahip olmalıdır. Bunun yanında verilen liste, tablo, indeks, çizelge, harita ve grafiksel gösterimlerde bilgiyi tanımlayabilmeli, yorumlayabilmeli ve kullanabilmelidir. Bu gösterimler sıklıkla sayılar ve yüzdeler gibi açık, belirgin nicel bilgileri içerir. Bu grafiksel gösterimlerin karmaşıklık seviyeleri çeşitli olabilir. Bazen basit bir bar grafiği veya daire grafiği olabilir, bazen de bir grafik çoklu bileşenlerden oluşabilir (Gal, 2004).

İstatistiksel Bilgi:İstatistiksel okuryazarlığın bilgi bileşenlerinden ikincisi istatistiksel bilgidir. Beş parçadan oluşur. Bunlar:

Niçin veriye ihtiyaç olduğunu ve verinin nasll elde edildiğini bilmek,

Tanımlayıcı istatistiklerle ilgili fikirler ve temel terimlere aşinalık,

Grafiksel ve çizelge gösterimleri ile ilgili fikirler ve temel terimlere aşinalık, Olasilı̆̆ın temel prensiplerini anlamak,

İstatistiksel sonuçlara ve çıkarımlara nasıl ulaşıldığını anlamaktır (Gal, 2004).

Niçin veri üretildiği ve veri toplamaya nasıl başlandığını bilmek araştırma tasarımının arkasındaki mantığın anlaşılmasına izin verir. Yetişkinler bu bilgiyi kullanabilmek için araştırma yöntemi kullanır (Moore, 1998). Araştırma yöntemi; deneysel metodu ve bir deney bir kontrol grubunun kullanılmasını, pilot çalışmaları, örneklemden evrene çıkarım yapmanın gerekliliğini, örneklemin mantığını ve temsil edilebilirlik düşüncesini içerir. Bunlara ek olarak kullanılan örneklem çeşidi önemlidir. Örneğin araştırmada uygun örneklem veya olasılıklı örneklem kullanıldı mı? (Gal, 2004). Tanımlayıcı istatistiklerle ilgili fikirler ve temel terimlere aşinalık, istatistiksel bilgi tabanı için ayrıca önem taşır. Tanımlayıcı istatistikler, yüzdeler ve merkezi eğilim ölçülerini (Mod, medyan, ortalama) içerir. Gal (1995) yetişkinlerin bu bilgiye ihtiyacı olduğunu kanıtlamaya çalışmıştır. Ortalamalar ve medyanlar bir veri setini özetlemenin için basit yollarındandır ve veri setinin merkezini gösterir. Ortalamalar uç değerlerde medyandan daha çok etkilenir ve tüm evreni temsil etmeyen hesaplamalarda örneklemin veri biçimi veya dağılımı, merkezi ölçümleri yanlış yönlendirebilir.

Bireyler grafiklerle ve çizelgelerle gösterimlere ve onların yorumlarına aşina olmalıdır. Grafik ve çizelgelerde yüzde veya sayılarla ilgili yanlış yönlendirmeler olduğunda bunları belirleyebilmelidir.

İstatistikler için bilgi tabanının bir başka parçası olasılığın temel normlarını anlama yeteneğidir. Çünkü yetişkinlerin karşılaştığı mesaj tiplerinde olasılık ve rastgele olaylar çok yaygındır. Bu mesajlar tahmin ediciler tarafindan değerlendirilir. Yetişkinler çeşitli yöntemlerle, örneğin, yüzde veya sözel değerlendirme yoluyla iletişim hakkında bilgi sahibi olmalıdır ve olasılık içeren iddiaları eleştirel olarak değerlendirebilmeli, anlayabilmeli ve olasılıklı değerlendirmelerin kaynağını tanımalıdır. Çünkü bazıları veri modelleme üzerine ya da öznel iddialar üzerine olabilir.

İstatistiksel bilginin son parçası istatistiksel sonuçlara ve çıkarımlara nasıl ulaşılacağını anlama yeteneğidir. Araştırma dizaynının veri toplamada çeşitli tipleri vardır. Bireyler örneklem metotlarında olabilecek farklı hataların veya olgunun nasıl ölçüleceğinin farkına varma ihtiyacı duyarlar. Bundan dolayı hatanın özel türleri uygun araştırma dizaynının başından sonuna kadar kontrol altında olmalıdır. Yetişkinler tarafından yorumlanması gerekli olan bir diğer değerlendirme türü hata payıdır. Çünkü medya tarafından siklıkla kullanılır (Gal, 2004).

Matematiksel Bilgi: Matematiksel bilgi, istatistiksel analiz nasıl yapılır sorusunun altında yatan hesaplamalardır. Örneğin yetişkinler ortalamanın bir veri setindeki en uç değerlerden nasıl etkilenebileceğini ve o veri setinin ortasını temsil etmeyebileceğini anlamak için aritmetik ortalamanın nasıl hesaplandığını anlama ihtiyacı duyarlar. Medya sık sık istatistiksel bilgileri yüzdelerle ve genellikle okulda öğrenilenlerden farklı olarak rapor eder. Örneğin, bazı yüzdeler \%100'den daha büyük olarak ifade edilir. Yüzdelerin matematiksel anlamı ve istatistiksel kullanımı da farklıdır. Onlar, bir sayıyı, bir ilişkinin açıklamasını, bir istatistiği, bir fonksiyonu veya olasılığın bir ifadesini temsil 
ediyor olabilir. Bunun yanında yüzdeler bir olayın koşullu olasılığı gibi veya ortalamanın \%15 altında gibi veya hata payının \%2 olması gibi kavramlarla ilişkili olan karmaşı ilişkileri temsil edebilir. Bireylerin istatistiksel okuryazar olabilmesi için gerekli matematik bilgisinin miktarı konusunda tartışmalar halen sürmektedir.

Bağlam: Verilerin nasıl ve nereden toplandığı istatistiksel mesajları doğru yorumlamak için önemlidir. Bireylerin dünya bilgisi ve bir bağlamdaki mesajların bir yere konması, istatistiklerle verilen çeşitli mesajların anlam kazanmasına izin verir (Gal, 2004). Bağlam sonuçların yorumlanması için temel ve anlama kaynağı, veri de bağlam içindeki sayılar olarak görülmelidir (Moore,1990). Bireyler, veri analizinde kullanılan süreçler ve araştırma yöntemi gibi veri oluşturma sürecine de aşina olmalıdır. Bağlam bilgisi, hata ve değişim için okuyucunun kaynaklara aşinalığının temel belirleyicisidir. Çünkü bu bilgi olmadan grup farklılıklarının niçin olduğunu ya da ne gibi alternatif açıklamalar olabileceğini veya bir çalışmanın nasıl yanlış tanımlanabileceği hayal etmek zor olur. Medyada bu yaygın bir problemdir. Medya tarafından gösterilen reklamlarda olduğu gibi kolaylıkla maskelenebilir veya okuyucuya bilgi çarpıtılarak sunulabilir. Gerçekte deneysel olmayan bir çalışmada, rapor hazırlayanlar çalışmanın geçerliliğini arttırmak için deney terimini kullanmaktadır (Gal, 2002).

Eleştirel Beceriler: Araştırma sonuçlarının eleştirel olarak değerlendirilmesi istatistiksel okuryazarlık için gerekli bir beceridir. Çünkü politikacılar, üreticiler veya reklamcılar gibi çeşitli kaynaklar tarafından üretilen genel medya bilgileri, onların ihtiyaçları ve amaçlarına bağlı olarak araştırma bulgularını objektif bir şekilde sunmayabilir. Gerçekte onlar verileri kasıtlı olarak önyargılı ve abartılı biçimde reklam yapmak için kullanabilirler. Bireylerde bir araştırmayı yorumlamada, istatistiksel haber hakkında veri nasıl toplandı ve nasıl analiz edildi sorularını sorma ihtiyacı oluşur. $\mathrm{Bu}$ soruların sorulmasında ve cevaplanmasında istatistiksel bilginin eleştirel bir değerlendirmesi, okuyucuların daha bilgili olmasına yardım edecektir.

\section{İstatistiksel Okuryazarlık Modelinin Ĕğilim Bileșenleri}

Gal (2002)'ın istatistiksel okuryazarlık modelinde eğilim bileşenleri, inançlar, tutumlar ve eleştirel tavırdır. Örneğin, istatistiksel haber ve bilgileri iletişim aracı olarak kullanma, tartışabilme gibi bireysel tepki verme yeteneği ile ilişkilidir. Bireylerin istatistiksel bilgiyi anlaması, bu bilginin etkileri veya verilen sonuçların kabul edilebilirliği hususundaki fikirlere olan ilgisini içerir (Gal, 2004). Aşağıda istatistiksel okuryazarlığın eğilim bileşenleri ayrıntılı olarak açıklanmıştır.

Eleştirel Tavır, İnançlar ve Tutumlar: İstatistiksel okuryazarlığın eğilim bileşenleri eleştirel tavır, inançlar ve tutumlardır. Eleştirel bir tavır almak bir iç süreç veya açıkça görülen bir süreç olabilir. Bireylerin akıllarında bazı eleştirel soruların doğması ve belirli bir araştırma raporunun anlamı hakkında düşünmesi bir iç süreçtir. Aile bireyleri veya meslektaşların yer aldığı araştırma bulgularının tartışıldığı bir süreç ise açık bir süreçtir. İstatistikler hakkında bireysel inançlar ve tutumlar, onların eleştirel bir tavır alma yeteneği ile iç içedir. Bu yüzden eğilim bileşenleri ayrı ayrı tartışılmıştır fakat gerçekte birbirine bağlıdır (Gal, 2002). Eleştirel bir tavır alma, dış çevreden bir ipucu olmaksızın nicel mesajlara sorgulayıcı bir tutum geliştirme yeteneğini içerir. Bireyler çeşitli tipteki araştırmaların sonuçlarını okuma, yorumlama ve karara varması gerektiğinde merak ettiği sorular listesine başvurmalıdır (Gal, 2002).

Bireylerin eleştirel bir tavır alma yeteneği ve onların araştırma sonuçlarının doğruluğunu tartışma istekliliği, onların inanç ve tutumlarıdır. İnanç ve tutumlar arasında ince bir ayrım vardır. İnançlar bireyin bir sosyal durum veya kendisi hakkında bireysel düşünce ve fikirlerinden oluşur (Wallman, 1993). İnançlar dengelidir ve değişikliğe tutumlardan daha az dirençlidir (Gal, 2002). Diğer yandan tutumlar, tekrar eden pozitif veya negatif duygulara zaman içinde cevap verme ile aşamalı olarak içselleşme yoluyla gelişen bir dereceye kadar dengeli yoğun duygulardır. Bu modelde istatistiksel okuryazarlık yedi bileşeni içine alacak şekilde dikkatlice tanımlanmıştır. İstatistiksel okuryazarlığı başarmak eğitim sürecinin önemli bir parçası olmasına rağmen birçok öğretim programında her zaman önemli bir parça olamamıştır. Eğitimde bugün niçin önemli olduğunu anlamak için matematik ve istatistik öğretimimin geçmişini anlamak gerekir.

\section{Watson ve Callingham Modeli}

Watson ve Callingham (2003), öğrencilerin istatistiksel okuryazarlık gelişimlerinin, öğrencilerdeki istatistiksel kavramların gelişimi ile nasıl ilgili olduğunu anlamak için, eğitimsel veya psikolojiksel bir temele dayanan bir model ortaya koymuşlardır. Watson ve Callingham (2003) çalışmasının güçlü yanı, 
onların 3.sınıftan 11.sınıfa kadar Avustralya'lı öğrencilerden oluşan büyük bir örneklem üzerinde istatistiksel okuryazarlık ölçeğini denemiş olmasıdır. $\mathrm{Bu}$, onlara istatistiksel okuryazarlık için öğretimin nasıl ve ne zaman meydana gelebileceğini ve öğrencilerin gelişmesine yardım etmek için nasıl bir yapı olması gerektiğini belirlemek için imkân sağlamıştır.

\section{Watson ve Callingham Modeli'nde İstatistiksel Okuryazarlık Bileşenleri}

Watson (2006) istatistiksel okuryazarlığın bileşenlerini ve bunlar arasındaki ilişkileri Şekil 2'de olduğu gibi ifade etmiştir. Bu bileşenlerden örneklem, veri temsili, merkezi eğilim ve yayılım ölçüleri, olasılık, çıkarım ve değişim matematik öğretim programlarında istatistik öğrenme alanı kazanımları içinde yer alan bölümlerdendir. Bunlardan farklı olarak Şekil 2'de bağlamın anlaşılması, okuryazarlık becerileri, genel matematiksel ve istatistiksel beceriler, görev biçimi ve görevi sürdürmeyi sağlayan görev motivasyonuna yer verilmiştir. Görev motivasyonu öğrencilerin istatistiksel okuryazarlık görevlerine yönelik tavırlarıyla ilgilidir. Watson (2006) istatistiksel okuryazarlık için gerekli olan matematiksel ve istatistiksel sorgulamanın ortaöğretime kadar çoğu öğrenci tarafından kazanılması gerektiğini belirtmiştir. Bağlam, istatistik okuryazarlığının çok önemli öğelerindendir. Öğrencilerin sorunun sorulduğu duruma yakınlıkları, o soruya ilgilerini daha da artırdığı bilinmektedir. Watson (2006) öğrencilerin bağlam bilgisini üç farklı şekilde değerlendirilebileceğini belirtmiştir. Bunlardan birincisi basit olasılıklar ve tablo okuma becerisi kazanıldıktan sonra öğrencilerin anlamakta zorlanmayacağı matematiksel bağlam görevleridir. İkincisi öğrencilerin okul yaşantıları ile ilgili bağlamlar içeren sınıf içi ve okul içi araştırmalarıdır. Sonuncusu ise medya verilerine dayanan ve potansiyel olarak okul dışı bağlamlar içeren görevlerdir. Karmaşık ve okul dışı bağlamların daha yüksek istatistiksel okuryazarlık performansı gerektirdiği açıktır. (Watson, 2006). Tüm bunların Şekil 2'deki diğer öğelerle bağlantılı olarak sonuç çıkarmaya yardım edeceği düşünülmektedir.

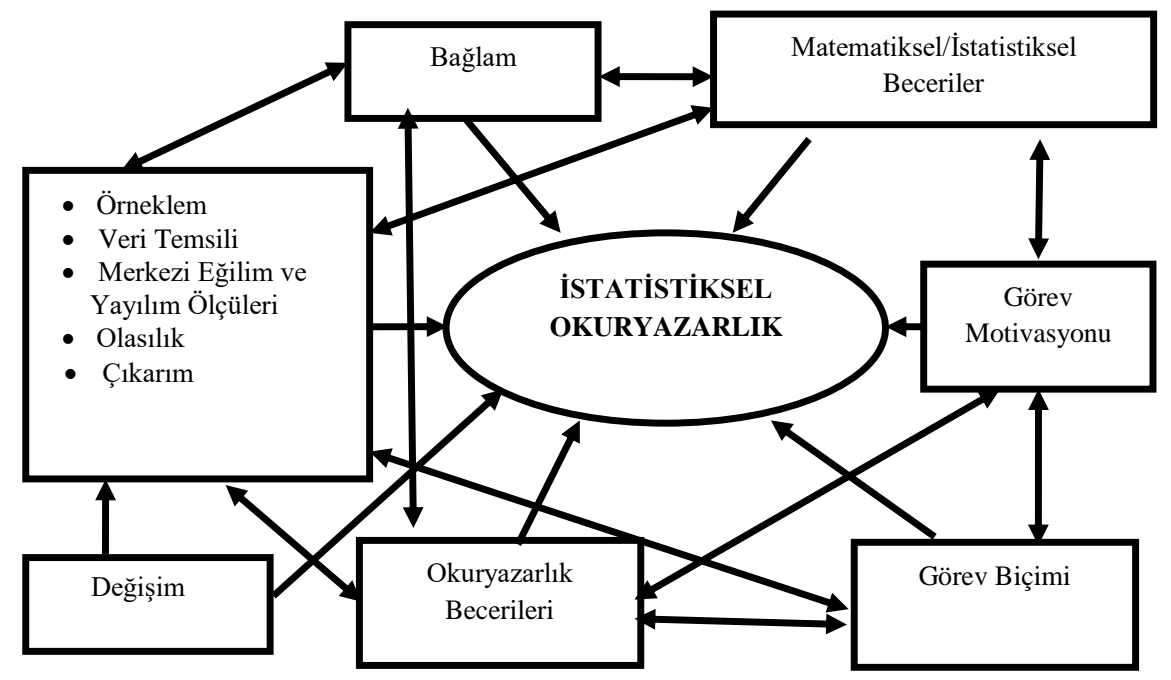

Şekil 2. İstatistiksel Okuryazarlık Bileşenleri

\section{Watson ve Callingham İstatistiksel Okuryazarlık Modeli Seviyeleri}

Watson ve Callingham (2003) tarafindan düzenlenen istatistiksel okuryazarlık modeli, Watson (1997) tarafından yapılan çalışmanın üzerine inşa edilmiş̧ir. Bu çalışma, gelişimsel psikolojiden, istatistiksel düşünmeye üç aşamalı bir hiyerarşiyi içermektedir ve Biggs ve Collis (1982)'in SOLO taksonomisine dayanmaktadır. Burada, istatistiksel okuryazarlık, istatistiksel düşünmeden ayrılamaz olarak düşünülmüştür. Bu modelin ilk aşamasında, öğrenciler, temel istatistik ve olasıllk terimlerini anlamaya çalışmaktadır. İkinci aşamada, bağlam içinde, istatistiksel terimleri ve kavramları anlamaya çalışmaktadır. En karmaşık seviyede ise bir sorgulama tutumu geliştirmekte ve eleştirel düşünmeyi kullanmaktadırlar. Daha sonra, Watson ve Callingham (2003), bu üç aşamalı görüşü, onların istatistiksel okuryazarlık yapıları içinde yeniden geliştirmiştir. Kişiye özgülükten, eleştirel matematiksele kadar, giderek karmaşıklaşan düşünceyi temsil eden altı seviyeli bir hiyerarşi oluşturmuşlardır. 
Watson ve Callingham (2003), geleneksel ders kitabı sorularının, seviye 1 ve seviye 2'nin gereksinimlerini yerine getirebildiğini, fakat, aynı soru tiplerinin, öğrencilerin eleştirel düşünmesine yardım edecek bağlamlara sahip olmadığını, motivasyon sağlama ihtiyacını karşılamada yetersiz olduğunu, öğretmenlerin, öğrencileri motive edecek, onların ilgisini çekecek bağlamları arayıp bulmak zorunda olacağını da belirtmektedir. Tablo 1'de Watson ve Callingham (2003) istatistiksel okuryazarlık modeli seviyeleri ve göstergeleri görülmektedir.

Tablo 1. İstatistiksel Okuryazarlık ModeliSeviyeleri ve Göstergeleri

\begin{tabular}{|c|c|}
\hline Seviyeler & Göstergeler \\
\hline $\begin{array}{l}\text { 6. Eleştirel } \\
\text { Matematiksel (Critical } \\
\text { Mathematical) }\end{array}$ & $\begin{array}{l}\text { Eleştirel olarak bağlam ile görevi sorgulama, özellikle medya veya olasılık } \\
\text { bağlamlarında orantısal muhakeme kullanma, belirsizlik durumlarında tahmin yapma } \\
\text { ihtiyacının değerini bilme ve dilin ince durumlarını yorumlama. }\end{array}$ \\
\hline 5. Eleştirel & $\begin{array}{l}\text { Eleştirel, orantısal muhakeme içermeyen fakat terminolojinin uygun kullanımını, } \\
\text { olasılığın nitel yorumunu ve değişimi değerlendirebilme, bilinen ve bilinmeyen } \\
\text { bağlamlarda görevi sorgulama. }\end{array}$ \\
\hline $\begin{array}{l}\text { 4. Tutarlı Eleştirel } \\
\text { Olmayan(Consistent } \\
\text { Non-Critical) }\end{array}$ & $\begin{array}{l}\text { Uygun, fakat bağlam ile ilgili eleştirel olmayan şekilde görev yapar. Terminoloji } \\
\text { kullanımının çoklu yönleri, sadece olasılığın geçtiği yerlerde değişimin } \\
\text { değerlendirilmesi ve ortalama, basit olasılıklar ve grafik özellikleri ile ilgili istatistiksel } \\
\text { beceriler. }\end{array}$ \\
\hline 3. Tutarlı Olmayan & $\begin{array}{l}\text { Çoğu kez destekleyici formatlarda, bağlam ile seçici görevlerde etkileşim, sonuçları } \\
\text { uygun fakat doğrulamaksızın fark etme ve istatistiksel fikirlerin nicel kullanımından } \\
\text { ziyade nitel kullanımı. }\end{array}$ \\
\hline 2. İnformal & $\begin{array}{l}\text { Sezgisel, istatistiksel olmayan inançlar, terminolojinin çok az kullanıldığı temel bir- } \\
\text { adım, açık tablo, grafik ve olasılık hesaplarını çoğu kez yansıtan cevaplar, bağlam ile } \\
\text { sadece konuşma diline özgü etkileşim. }\end{array}$ \\
\hline $\begin{array}{l}\text { 1. Kişiye Özgü } \\
\text { (Idiosyncratic) }\end{array}$ & $\begin{array}{l}\text { Bağlam ile kişiye özgü yükümlülük, terminolojinin gereksiz tekrar yapan kullanımı ve } \\
\text { birebir sayma ve tablolardaki hücre değerlerini okumaya ilişkin temel matematiksel } \\
\text { beceriler. }\end{array}$ \\
\hline
\end{tabular}

Watson (2003), öğrenciler okuldan ayrılıncaya kadar istatistiksel okuryazarlık inşasının altıncı seviyesine ulaşmasının amaç olduğunu, fakat büyük ihtimalle ilerlemenin bundan önceki seviyelerinin bir değerlendirmesi olmaksızın, anlamanın daha yüksek seviyeleri için öğrencilere yardım edecek deneyimleri planlamanın mümkün olmadığını ifade eder. Watson (2003), gözlemlenen gelişimin seviyeleri ile yıl seviyelerini karşılaştırmaya teşebbüs etmemiştir, bununla beraber, mecburi okullaşmanın sonunda, birçok öğrenci, yukarıda tarif edilen en yüksek seviyelerde istatistiksel okuryazarlık sergilemediğini gözlemlemiştir. Tablo 2'de Watson ve Callingham (2003) modelindeki 1.seviyede herbir bileşen ile ilgili göstergeler görülmektedir.

Tablo 2. İstatistiksel Okuryazarlık Modeli1.Seviye (Kişiye Özgü) Göstergeleri

\begin{tabular}{|c|c|}
\hline Bileşenler & Göstergeler \\
\hline Bağlam & Bağlantı yok, kişiye özgü, kişisel. \\
\hline Örneklem & $\begin{array}{l}\text { Öğrenciler örneklem seçerken kişisel inanışlarını yansıtırlar. Uygun olmayan örneklem } \\
\text { örnekleri verirler. }\end{array}$ \\
\hline Veri Temsili & $\begin{array}{l}\text { Öğrenciler basit grafik ve tabloları okuyabilirler. Örneğin iki yönlü iç içe olmayan bir } \\
\text { tablodan belirli değerleri okuyabilir, bir sıra ya da sütundan en yüksek değeri seçebilirler, bir } \\
\text { resimli grafikten doğru şekilde sayabilir. }\end{array}$ \\
\hline Ortalama & $\begin{array}{l}\text { Öğrenciler ortalama hesapları içeren sorulara cevap veremez. Öğrenciler mod, medyan, } \\
\text { aritmetik ortalama kavramlarına uzaktır. }\end{array}$ \\
\hline Olasılık & Kişiye özgü nedenler, uygun olmayan olasılık yorumları. \\
\hline Çıkarım & $\begin{array}{l}\text { Öğrenciler tablo veya veri gösterimlerinden çıkarım yapamaz veya hayali açıklamalar } \\
\text { yaparlar. }\end{array}$ \\
\hline Varyasyon & $\begin{array}{l}\text { Öğrenciler bu seviyede varyasyon terimini bilmezler veya varyasyon ile ilgili sorgulamalar } \\
\text { kişiye özgü olur. Belki bu terim başka bir terimle karıştırılır. Öğrenciler sadece grafiklerdeki } \\
\text { farklılıkları fark eder. Olasılıkla ilgili değerlendirmeler yapamaz. }\end{array}$ \\
\hline $\begin{array}{l}\text { Matematiksel } \\
\text { İstatistiksel } \\
\text { Beceriler }\end{array}$ & $\begin{array}{l}\text { Birebir sayma, bir resimli grafikteki sıralar arasındaki farklılıkları bulma, tablodaki girişleri } \\
\text { belirleme, en büyük sayıyı seçme, sütun toplamı oluşturmak için iki girişi toplama. }\end{array}$ \\
\hline
\end{tabular}


Tablo 3. İstatistiksel Okuryazarlık Modeli2.Seviye (İnformal) Göstergeleri

\begin{tabular}{|c|c|}
\hline Bileşenler & Göstergeler \\
\hline Bağlam & Konuşma diliyle anlatım. \\
\hline Örneklem & $\begin{array}{l}\text { Örneklemin tek bir özelliğine odaklanma vardır. Uygun olmayan örneklem seçimi ve bunları } \\
\text { kişiye özgü düşüncelerle destekleme vardır. }\end{array}$ \\
\hline Veri Temsili & $\begin{array}{l}\text { Öğrenciler tablolarda basit karşılaştırmalar ve hesaplamalar yapabilir, bir grafikte en yüksek } \\
\text { ve en küçük veri değerini belirleyebilirler. Karmaşık bir bağlamda grafik yorumlama ve } \\
\text { hesaplamada uygun olmayan kişiye özgü aritmetik işlemler yaparlar. İki değişken arasındaki } \\
\text { ilişskiyi grafikle göstermede bağlamla ilgisi olmayan veri temsilleri yaparlar. }\end{array}$ \\
\hline Ortalama & $\begin{array}{l}\text { Öğrenciler ortalamanın anlamı hakkında tek, konuşma diline özgü yanıtlar veya örnekler } \\
\text { verirler. Onun anlamını daha fazla açıklayamaz. Mod ve medyan ile ilgili tanımları yanlıştır. }\end{array}$ \\
\hline Olasılık & Kişiye özgü, konuşma dilinde yorumlamalar, "her şey mümkün" \\
\hline C1karım & Öğrenciler çıkarım ve karar verme ile ile ilgili görevlerde tutarsız cevaplar verirler. \\
\hline Varyasyon & $\begin{array}{l}\text { Öğrenciler çıkarım yaparken veya karar verirken istatistiksel olmayan yönlere odaklanırlar. } \\
\text { Öğrenciler olasılıkla ilgili varyasyonu anlamaya başlar fakat olasılıkla ilgili hesaplamalarda } \\
\text { esnek olmayan tahminler yaparlar. Bu aşamada öğrencilerin pek çok durumda olasılık } \\
\text { bağlamlarında varyasyonun ortaya çıtığını bildikleri; fakat buna uygun sınırlar } \\
\text { koyamadıkları görülmektedir. }\end{array}$ \\
\hline $\begin{array}{l}\text { Matematiksel } \\
\text { İstatistiksel }\end{array}$ & $\begin{array}{l}\text { Bir aşamalı tablo ve grafik hesaplamaları, bir aşamalı basit olasılık değerlendirmeleriyle } \\
\text { ilgilidir. Bazı istatistikî terimler anlaşılmaya başlansa da, tek maddeli tanımlarla sınırlıdır. }\end{array}$ \\
\hline Beceriler & Bağlamın uygun şekilde anlaşılması hala çok kısıtlıdır. \\
\hline
\end{tabular}

Tablo 4. İstatistiksel Okuryazarlık Modeli3.Seviye (Tutarlı Olmayan) Göstergeleri

\begin{tabular}{|c|c|}
\hline Bileşenler & Göstergeler \\
\hline Bağlam & Seçici ve tutarsız bağlantı \\
\hline Örneklem & Öğrenciler uygun olmayan özelliklere odaklanırlar. \\
\hline Veri Temsili & $\begin{array}{l}\text { Öğrencilerden bir grafik taslağı çizmeleri istendiğinde, basit etiketsiz grafikler ya da ilişkiyi } \\
\text { göstermekte başarısız olan etiketli grafikler üretirler. Görevi kavrarlar fakat tam bir grafik } \\
\text { oluşturmak için tüm maddeleri bir araya getiremezler. }\end{array}$ \\
\hline Ortalama & $\begin{array}{l}\text { Ortalama kavramı, öğrencilere sorun oluşturmaya devam eder. Formül ihtiyacının } \\
\text { tanınmasının konuşma diliyle yorumlanması vardır. }\end{array}$ \\
\hline Olasılık & Formül ihtiyacının tanınmasının konuşma diliyle yorumlanması görülür. \\
\hline Çıkarım & Öğrencilerin çıkarımları genelde merkez dışı konulardan oluşur. \\
\hline Varyasyon & $\begin{array}{l}\text { Olasılık bağlamlarında varyasyona seslenilse de, örnekler gerçekçi olmamaktadır. } \\
\text { Varyasyonun anlaşılmasında gelişme görülmesi sadece bu aşamada sınırlı düzeydedir. } \\
\text { Öğrenciler niteliksel sorgulamanın yeterli olduğu bağlamlarda, ya da bir listeden uygun }\end{array}$ \\
\hline $\begin{array}{l}\text { Matematiksel } \\
\text { İstatistiksel } \\
\text { Beceriler }\end{array}$ & $\begin{array}{l}\text { yanıtın seçilmesi istenen görevlerde daha fazla başarı gösterirler. Uygun yanıtın seçildiği } \\
\text { durumlarda, seçme nedeninin doğru olarak açıklanması ise yetersiz olmaktadır. Gelişmiş } \\
\text { matematik ve istatistik becerileri, ortalama ve yüzde riskinin oluşturulması ya da } \\
\text { yorumlanması değil ama tanınması görülmektedir }\end{array}$ \\
\hline
\end{tabular}

Tablo 3 ve Tablo 4'te Watson ve Callingham (2003) modelindeki 2. ve 3. seviyede herbir bileşen ile ilgili göstergeler görülmektedir. 
Tablo 5. İstatistiksel Okuryazarlık Modeli4.Seviye (Tutarlı Eleştirel Olmayan) Göstergeleri

\begin{tabular}{|c|c|}
\hline Bileşenler & Göstergeler \\
\hline Bağlam & Genellikle uygun fakat eleştirel değil \\
\hline & Örnekleme açısından, öğrenciler kavramı açıklamakta çoklu öğeler kullanırlar fakat bu \\
\hline Örneklem & $\begin{array}{l}\text { öğeler birbirini tutmaz. Tanıdık, okul temelli sosyal bir bağlamda eleştirel sorgulamaya geçiş } \\
\text { görülür. }\end{array}$ \\
\hline & $\begin{array}{l}\text { Bağlam, grafik görevlerinde öğrenci başarısında önemli rol oynar. Öğrenciler veri } \\
\text { gösterimlerinde en yüksek veri değerini ve dizisini bulabilir, grafiğin türünü tanımlarken }\end{array}$ \\
\hline Veri Temsili & $\begin{array}{l}\text { uygun niteliksel açıklamalar yapabilir. Veri gösteriminin etkiliğini değerlendirebilir, anlamlı } \\
\text { nedenler sunabilir. Nedensel bir iddianın temsili için bir grafik çizmeleri oluşturabilir, kısmi } \\
\text { bir ilişki kurabilirler. }\end{array}$ \\
\hline Ortalama & $\begin{array}{l}\text { Öğrenciler ortalama ve medyanın işlemsel uygulamalarını yapabilir. Ortalamaya dayalı } \\
\text { görevlerde, öğrenciler ortalama algoritmasını ve bir veri setinin ortasının nasıl } \\
\text { bulunabileceğini tarif edebilmekte, fakat bir aykırı değerin etkisini fark edemezler. }\end{array}$ \\
\hline Olasılık & Bağlama bağlı olarak karışık başarı görülür. \\
\hline Çıkarım & $\begin{array}{l}\text { Öğrenciler çıkarım söz konusu olduğunda, yargı ve tahmin oluştururken merkezi konuların } \\
\text { farkına varmakta tutarsızlık gösterirler. Fakat veri-temelli sorgulama yaparlar. Öğrenciler } \\
\text { neden-sonuç ilişkisi yerine gerçek sayılarının ne olduğuna odaklanırlar. Bu durum eleştirel } \\
\text { sorgulama becerileri olmadan bağlamın farkına varıldığını gösterir. }\end{array}$ \\
\hline Varyasyon & Olasılığa bağlı olarak varyasyonun anlaşılması bu aşamada görülür. \\
\hline $\begin{array}{l}\text { Matematiksel } \\
\text { İstatistiksel } \\
\text { Beceriler }\end{array}$ & $\begin{array}{l}\text { Bu aşamada matematiksel ve istatistiksel beceriler ortalama, basit olasılık, grafik } \\
\text { özellikleriyle ilgilidir. Varyasyon olasılık ortamlarında uygun şekilde gösterilmekte ve çoğu } \\
\text { tanımlamalar kavramın çoklu yönlerini ortaya çıkarmaktadır. Çoğu bağlamın özelliklerinin } \\
\text { anlaşılması, kavramların eleştirel olmasa da mantıklı şekilde uygulandığına işaret etmektedir. }\end{array}$ \\
\hline
\end{tabular}

Tablo 6. İstatistiksel Okuryazarlık Modeli5.Seviye (Eleştirel) Göstergeleri

\begin{tabular}{|c|c|}
\hline Bileşenler & Göstergeler \\
\hline \multirow[t]{2}{*}{ Bağlam } & Eleştirel bağlantılar görülür. \\
\hline & Örnekleme görevlerinde, öğrenciler bir örneği ve amacını tarif ederken çeşitli elementleri \\
\hline \multirow{3}{*}{ Örneklem } & birbirlerine bağlarlar. Öğrenciler rastgele örnekleme yöntemleri sunarlar. Öğrencilerin \\
\hline & kullandığ örnekleme yöntemleri uygun kararlar ve istatistiksel doğrulamalar içerir. Genel \\
\hline & $\begin{array}{l}\text { olarak, daha tanıdık baglamlarda, ogrencıler ornekleme konularıyla bu aşamada başa çıkarlar. } \\
\text { Öğrenciler grafik oluşturmada iddiayı resmeden uygun grafik taslağını çizebilirler. Bu durum }\end{array}$ \\
\hline Veri Temsili & $\begin{array}{l}\text { iki değişkenle aynı anda uğraşabilme yeteneğini temsil etmekte ve uygunluğun arttığını } \\
\text { gösterir. Grafikte olağandışı durumları varsa fark edebilir grafiğin parçalarına daha dikkatli } \\
\text { odaklanır. }\end{array}$ \\
\hline Ortalama & $\begin{array}{l}\text { Öğrenciler ortalama düşüncesi açısından, küçük bir veri setinin medyanını ve aritmetik } \\
\text { ortalamasını bulabilme yeteneği gösterirler. }\end{array}$ \\
\hline Çıkarım & Bir önceki aşamaya göre çok az bir değişim görülür. \\
\hline Olasılik & Koşullu görevlerde başarı \\
\hline Varyasyon & $\begin{array}{l}\text { Öğrencilerin varyasyonu anlaması bu aşamadaki görülmeye başlar. Öğrenciler verideki bir } \\
\text { artışa, zamanla değişime odaklanmakta, ya da grafiğin görsel yapısında varyasyonu açık bir } \\
\text { şekilde anlayabilirler. }\end{array}$ \\
\hline Matematiksel & \\
\hline $\begin{array}{l}\text { İstatistiksel } \\
\text { Beceriler }\end{array}$ & Bir önceki aşamaya göre çok az bir değişim görülür. \\
\hline
\end{tabular}

Tablo 5, Tablo 6 ve Tablo 7'de deWatson ve Callingham (2003) modelindeki sirasiyla 5, 6 ve 7.seviye için her bileşen ile ilgili göstergeler görülmektedir. 
Tablo 7. İstatistiksel Okuryazarlık Modeli6. Seviye (Eleştirel Matematiksel) Göstergeleri

\begin{tabular}{|c|c|}
\hline Bileşenler & Göstergeler \\
\hline Bağlam & $\begin{array}{l}\text { Öğrenciler oransal sorgulama içeren eleştirel bağlantılar kurabilir. Daha az bilinen } \\
\text { bağlamlarda eleştirel düşünme görülür. }\end{array}$ \\
\hline Örneklem & $\begin{array}{l}\text { Öğrenciler örneklem seçmede ya iki farklı rastgele yöntem ya da rastgele ve temsili } \\
\text { yöntemlerin bir kombinasyonunu seçebilirler. }\end{array}$ \\
\hline Veri Temsili & $\begin{array}{l}\text { Öğrenciler grafik oluşturma açısından, tablo ve grafiklerde sadece veri okumak yerine } \\
\text { bağlamı da içeren iki özet yargı oluşturabilirler. Okullardaki formal eğitime bağlı olarak, } \\
\text { mod terminolojisi bir nokta yığını şemasına bağlı olarak fark edilebilir. Sütun grafiklerinde } \\
\text { ilgili oran hesaplamaları doğru şekilde tamamlanabilir. }\end{array}$ \\
\hline Ortalama & Öğrenciler aykırı değerlerin yanıltıcı etkisinin anlamaya başlar. \\
\hline Çıkarım & $\begin{array}{l}\text { Bu aşamada çıkarım, düşünmedeki derin bağları ortaya çıkarmaktadır. Yapılan tahminler } \\
\text { belirsizlik ifadeleri içerir. Grafiklerin değerlendirilmesi yanında belirsizlik durumu da } \\
\text { değerlendirilir. Olma olasılığı yüksek olan durum fark edilir ve ifade edilir. Eleştirel } \\
\text { sorgulama açısından öğrenci kendine neden sonuç ilişkisi ile ilgili önemli soruları sorar. }\end{array}$ \\
\hline Olasilık & $\begin{array}{l}\text { Daha ayrıntılı matematik gerektiğinde başarı, niteliksel tanımlamalar yerine niceliksel } \\
\text { sorgulama vardır. Oransal sorgulama, bağımsız olayları dikkate alma ve bunlarla ilgili doğru } \\
\text { hesaplamalar görülür. }\end{array}$ \\
\hline Varyasyon & Bir önceki aşamaya göre değişim görülmez. \\
\hline & Beceriler, oran ve uygun parça-bütün yorumlamalarını içeren oransal sorgulama, fiyatları \\
\hline Matematiksel & hesaplamada oranları kullanabilme, bağımsız olay ve olasılık hesaplamalarındaki etkilerinin \\
\hline İstatistiksel & anlaşılması, genel niteliksel olasılık görüşü ve "mod" gibi terimleri ezberlemeyi \\
\hline Beceriler & $\begin{array}{l}\text { içermektedir. En yüksek performansı elde etmek için tüm bunlar dil ve bağlamdaki derin } \\
\text { bağları anlama yeteneği ile birleştirilir. }\end{array}$ \\
\hline
\end{tabular}

Watson ve Callingham (2003) tarafından geliştirilen bu modelde açıklanan altı seviye incelendiğinde, seviye 1 ve seviye 2 de öğrencilerin, sadece istatistiksel terimlerin anlamları ve dil ile etkileşim halinde olduğu, seviye 3 ve seviye 4'deki öğrencilerin, bağlam ile uğraşmaya ve bağlam içinde gömülü istatistiği ortaya çıkarmaya başladığı, sınıflandırmanın son iki seviyesi olan seviye 5 ve seviye

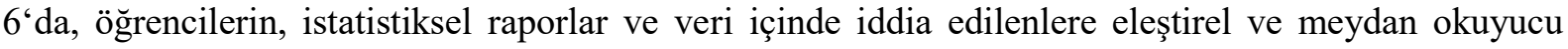
olabildikleri söylenebilir.

\section{TARTIŞMA ve SONUÇ}

Gal'ın (2002) istatistiksel okuryazarlık modeli bir kişinin "anlamasını, açıklamasını, eleştirel olarak değerlendirmesini ve istatistiksel mesajlara göre davranmasını" mümkün kılan bilgi türlerini (okumayazma becerileri, istatistiksel bilgi, matematiksel bilgi, bağlam bilgisi ve eleştirel sorular) ve eğilimleri (inançlar, tutumlar, eleştirel duruş) ortaya koymaktadır. Gal'a göre bu bilgi tabanları ve eğilimler örtüşmektedir ve bir kişi istatistiksel bir durumla karşılaş̧ı̆̆ zaman bunlar arasında etkileşimler meydana gelmektedir. Gal (2002) bu durum için şu örneği vermiştir; "bir dinleyici eğer verinin toplandığı bağlama aşina değilse gruplar arasındaki bir farkın nasıl oluştuğunu, belirli değişkenler arasındaki bir ilişki hakkında rapor edilen bulgular için hangi alternatif açıklamaların olabileceğini veya bir çalışmanın nasıl yanlış gidebileceğini hayal etmek daha zor hale gelmektedir”. Gal (2002) istatistiksel okuryazarlık modeli tüm bireyleri amaçlamış olmasına rağmen okul ortamındaki öğrenciler için de uygulanabilirdir. Watson ve Callingham (2003) modeli, öğrencilerle sınıf içinde çalışan istatistik eğitimcilerinin çalışması sonucu ortaya çıkmıştır. Bir öğretim uygulamasının etkisini, hedeflere ulaşmada öğrencilerin nereden başladığı ve nasıl ilerleme kaydettiklerinin ele alınması, öğrencilerin bir performans seviyesinden daha yüksek olanına geçmelerine yardım etmek için hangi adımların atılabileceğini ortaya koyulması açısından bu model oldukça yararlıdır. Bu iki istatistiksel model, istatistiksel okuryazarlığ 1 tarif etmek için, hiçbir şekilde, tek başına geçerli modeller değillerdir.

Gal (2002) istatistiksel okuryazarlık modelinin bilgi ve eğilim bileşenleri ile Watson ve Callingham(2003) istatistiksel okuryazarlık modeli istatistik eğitimi üzerinde etkili olmuştur. Her iki modelin de önemli yönü istatistiksel bilgilerde önyargı ve hatalara aşina olmanın veya eleştirel sorgulamanın insanlar için bir ihtiyaç olduğunun vurgulanmasıdır. Watson medya raporlarında iddia edilenlere karşı koymada öğretmenlerin sürekli sonuçları sorgulaması gerektiğini böylelikle öğrencilerin güven sahibi olabileceği sonucuna varmıştır. Watson medyadan seçilen makalelerden 
uygun eleştirel sorular elde edilebileceğini savunmuştur. Hatta öğrencilerin erken yaşlarda istatistiksel sorgulamalara başlamaları için bu sorularla ilkokulda tanışması gerektiğini tavsiye etmiştir. Bir öğretme ve öğrenme aracı olarak medyada yer alan makalelerin kullanımı öğrencilerin istatistiksel okuryazarlığını gelişimini arttırabilir. Öğrencilerin istatistiksel okuryazarlığa doğru motivasyonları, görevlere gömülü olan bağlamlardan etkilenebilir (Watson, 2006). Bu nedenle öğretmenlerin, öğrencilerin ihtiyaç duyduğu bu bağlamları seçmesi gerekir. İnsanların çoğu istatistikleri sorgulamamaktadır (Best, 2004). Eğer bu ifade yaygın olarak yetişkinler için kullanıliyorsa, bu durumda öğrencileri hayata hazırlayan öğretmenlerin de istatistiksel okuryazarlık ve modelleri anlama ihtiyac1 vardır.

Gal'ın (2002) yaklaşımı ve Watson ve Callingham (2003) tarafından inşa edilen yapı arasında bazı açık farklar vardır. Gal, ihtiyaç duyulan gerekli bileşenler boyunca istatistiksel okuryazarlığın tam bir tanımını sunar. Bununla beraber, Watson ve Callingham (2003), istatistiksel okuryazarlığın hiyerarşik seviyeleri arasında ayırım yapar. Daha önce bahsedildiği gibi, farklı yaklaşımlar, sırasıyla, yetişkinler ve öğrenciler üzerindeki çalışmaların bağlamlarıyla anlaşılabilir. Her şeye rağmen, hem Gal'ın hem de Watson ve Callingham (2003)'in tanımlamalarının özü, çok benzerdir. İkisi de istatistiksel bilgi ve becerilere, fikirlerle haberleşme yeteneğine, bağlamın merkezi pozisyonuna ve eleştirel olma ihtiyacina vurgu yapar. Hem Watson ve Callingham (2003) hem de Gal (2002)'in istatistiksel okuryazarlık tanımlarında, "eleştirel olmaya" açık referanslar vardır. Hem Gal (2002) hem de Watson ve Callingham (2003), tutumları ve inançların modelleri içinde olması gereken eğilimler olarak görmüşlerdir.

Bilgi yüklü günümüz toplumunda, istatistiksel bileşenleri içeren raporları eleştirel olarak değerlendirme ve yorumlama yeteneği, her şeyden önemlidir. Literatür istatistikî bilgilerin değerlendirilmesinin üst düzey düşünme becerisi kategorisinde yer alabileceğini desteklemektedir. Üst düzey düşünme becerilerini, istatistiğin işlem ve yöntemleri gibi alt düzey düşünme becerilerine odaklanan geleneksel öğretim ve değerlendirme ile öğretmek kolay olmayabilir. Garfield ve Ben-Zvi (2008), öğretmenlerin istatistiksel argümanların dâhil olduğu sınıf söylemlerini geliştirmesi ve istatistiksel olarak anlamlı fikirlere odaklanmayı sürdürmesi gerektiğini belirtmişlerdir.

$\mathrm{Bu}$ çalışmada ülkemizde son yıllarda matematik öğretim programında daha çok vurgu yapılan istatistiksel okuryazarlık konusuna öğretim ve araştırma açısından dikkat çekilmek istemiştir. $\mathrm{Bu}$ doğrultuda istatistiksel okuryazarlığın gelişim modelleri incelenmiştir. $\mathrm{Bu}$ modeller öğrencilerin istatistiksel okuryazarlığının tutarlı bir resmini verebilir, öğretim uygulamaları ve planlamaları için öğretmenlere bilgi tabanı sağlayabilir. Aynı zamanda farklı seviyelerde beklenen istatistiksel okuryazarlık türleri konusunda yararlı bilgiler sağlar. Öğrencilerin istatistiksel teknik ve becerilerini geliştirebileceği ders kitaplarının hazırlanmasında, kitap yazanlara yol gösterici olabilir.

\section{KAYNAKLAR}

American Statistical Association. (2005). Guidelines for assessment and instruction in statistics education: College report. Alexandria: Author.

Best, J. (2004). More damned lies and statistics: How numbers confuse public issues. California, CA: University of California Press.

Biggs, J., \& Collis, K. (1982). Evaluating the quality of learning: The SOLO taxonomy. New York, NY: Academic Press.

delMas, R. C. (2002). Statistical literacy, reasoning, and learning: A commentary. Journal of Statistics Education, 10(3).http://www.amstat.org/publications/jse/v10n3/delmas_discussion.htmladresinden elde edildi.

Callingham, R., \& Watson, J. M. (2005). Measuring statistical literacy. Journal of Applied Measurement, 6 (1),29, 19-47.

Gal, I. (1995). Statistical tools and statistical literacy: The case of the average. Teaching Statistics, 17, 97-99.

Gal, I. (2002). Adult statistical literacy: Meanings, components, responsibilities. International Statistical Review, $70(1), 1-25$

Gal, I. (2004). The Challenge of Developing Statistical Literacy, Reasoning and Thinking. İçinde, Ben-Zvi, D.,\& Garfield, J.(Ed.),Statistical Literacy - Meanings, Components, Responsibilities (pp.47-78). America: Kluwer Academic Publishers.

Hooke, R. (1983). How to tell the liars from the statisticians. New York, NY: Marcel, Dekker. 
Lehohla, P. (2002). Promoting statistical literacy: A South African perspective. İçinde B. Phillips, (Ed.), Proceedings of the Sixth International Conferences on Teaching Statistics. Voorburg, the Netherlands: International Statistical Institute.

Makar, K., \& Rubin, A. (2009). A framework for thinking about informal statistical inference. Statistics Education Research Journal, 8(1),82-105.

Milli Eğitim Bakanlığı (2009).Matematik dersi (6-8. sınflar) öğretim programı ve matematik dersi (9-12.sınıflar) ögretim programı.http://ttkb.meb.gov.tr/www/ogretim-programlari/icerik/72 adresinden elde edildi.

Milli Eğitim Bakanlığı (2013). Ortaokul matematik dersi (5, 6, 7 ve 8. sınıflar) öğretim programı ve ortaöğretim matematik dersi $(9,10,11$ ve 12. sinıflar) öğretim programı.http://ttkb.meb.gov.tr/www/guncellenenogretim-programlari/icerik/151adresinden elde edildi.

Moore, D.S. (1998). Statistics among the liberal arts. Joumal of the American Statistical Association, 93(444), 1253-1259.

Moore, D (1990) Uncertainty. İçinde L Steen (Ed. ), On the shoulders of giants: New approaches to numeracy (pp. 95-137). Washington, DC: National Academy Pres.

National Council of Teachers of Mathematics. (2000). Principles and standards for school mathematics. Reston, VA: Author.

Rumsey, D. J. (2002). Discussion: Statistical literacy: Implications for teaching, research and practice. International Statistical Review, 70, 32-36.

Shaughnessy, J. M. (2007). Research on statistics learning and reasoning. İçinde F. K. Lester (Ed.), Second handbook of research on mathematics teaching and learning (pp. 957-1009). Reston, VA: The National Council of Teachers of Mathematics.

Shaughnessy, J. M., \& Pfannkuch, M. (2004). How faithful is old faithful? Statistical thinking: A story of variation and prediction. Mathematics Teacher, 95(4),252-259.

Snell, L. (1999). Using Chance media to Promote Statistical Literacy. Statistical Meetings, Dallas, TX.

Wallman, K. K. (1993). Enhancing statistical literacy: Enriching our society. Journal of the American Statistical Association, 88(421),1-8.

Watson, J. M. (1997). Assessing statistical literacy using the media. İçinde I. Gal \& J. B. Garfield (Eds.), The assessment challenge in statistics education (pp. 107-121). Amsterdam, The Netherlands: IOS Press \& The International Statistical Institute.

Watson, J. M., \& Callingham R. (2003). Statistical literacy: A complex hierarchical construct. Statistics Education Research Journal, 2(2),3-46.

Watson, J. M. (2006). Statistical literacy at school: Growth and goals. Mahwah, NJ: Lawrence Erlbaum. 